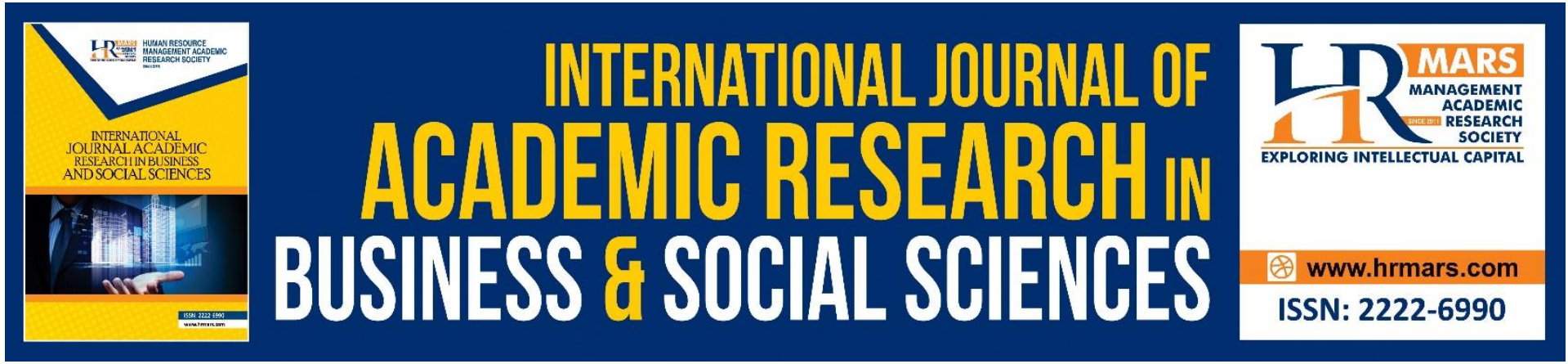

\title{
Understanding Technostress During the Era of Covid-19: A Conceptual Paper
}

Norshiba Norhisham

To Link this Article: http://dx.doi.org/10.6007/IJARBSS/v11-i8/10628

DOI:10.6007/IJARBSS/v11-i8/10628

Received: 14 June 2021, Revised: 20 July 2021, Accepted: 03 August 2021

Published Online: 28 August 2021

In-Text Citation: (Norhisham, 2021)

To Cite this Article: Norhisham, N. (2021). Understanding Technostress During the Era of Covid-19: A Conceptual Paper. International Journal of Academic Research in Business and Social Sciences, 11(8), 1936-1947.

\section{Copyright: @ 2021 The Author(s)}

Published by Human Resource Management Academic Research Society (www.hrmars.com)

This article is published under the Creative Commons Attribution (CC BY 4.0) license. Anyone may reproduce, distribute, translate and create derivative works of this article (for both commercial and non-commercial purposes), subject to full attribution to the original publication and authors. The full terms of this license may be seen at: http://creativecommons.org/licences/by/4.0/legalcode

Vol. 11, No. 8, 2021, Pg. 1936 - 1947

http://hrmars.com/index.php/pages/detail/IJARBSS

Full Terms \& Conditions of access and use can be found at http://hrmars.com/index.php/pages/detail/publication-ethics 


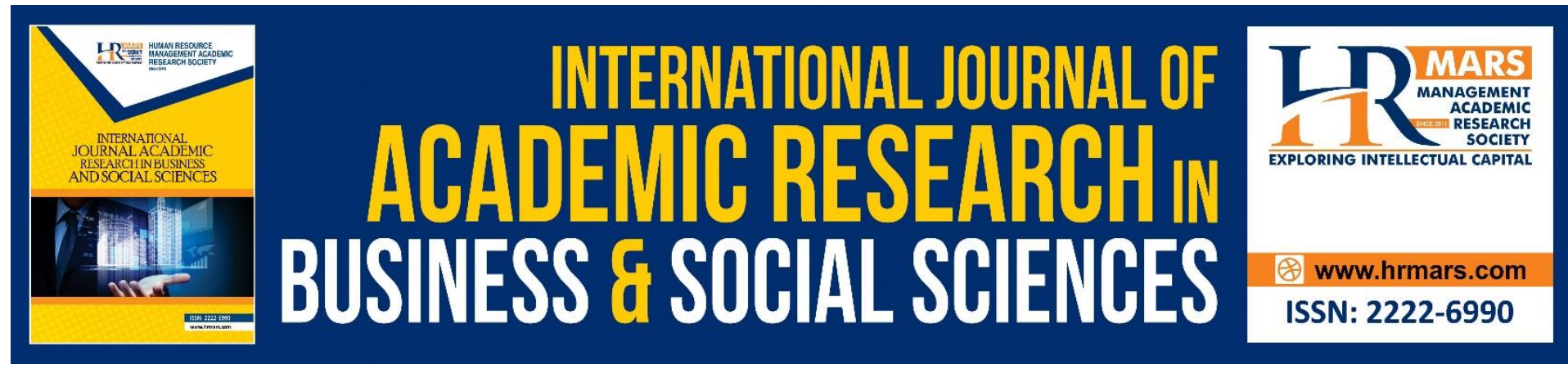

\title{
Understanding Technostress During the Era of Covid-19: A Conceptual Paper
}

\author{
Norshiba Norhisham \\ Universiti Teknologi Mara (UiTM), Melaka Malaysia \\ Email: shibahisham@uitm.edu.my
}

\begin{abstract}
Since the beginning of digitalisation, employees are faced with the need to adapt to technology and ICTs. It is deemed to be one of the crucial skills possessed by an individual. As much as this is well needed before, the current situation where remote working is a must due to Covid-19 lockdown requires employees to upgrade their technology-related skills. The obligation to upgrade their ICT skills and use ICT fully in task creates anxiety and stress, namely technostress. This paper is discussing technostress conceptually including different dimensions in technostress (creators and prohibitors) and how each dimension affecting the individual as an ICT user. Furthermore, eustress is introduced as a new dimension in technostress. With limitations and suggestions for future researchers, this paper is thought to contribute to the topic of technostress and understanding its context.
\end{abstract}

Keywords: Technostress, Covid-19, Technostress Creators, Technostress Prohibitors, TechnoEustress

\section{Introduction}

Since December 2019, the world has been impacted by the pandemic of Covid-19. This pandemic has had a great impact on health, economy, and society, causing difficulties and uncertainty for many people in countries across the world (Zito et al., 2021), including Malaysia. The government has adopted security measures such as social distancing which is considered the most effective way to flatten the spreading of the virus (Matrajt \& Leung, 2020). Since March 2020, the Malaysian government has enforced strict Movement Control Order on different phases, forcing both private companies and public administrations to work remotely. Companies are forced to arrange remote working and rely fully on technologies, in some cases even without proper training in ICT, leading to some negative implications in terms of employees' wellbeing and technostress (Christian et al., 2020; Zito et al., 2021). Employees are forced to stay at home and working remotely from the office, creating tension and exhaustion. Employees are also needed to work with multiple systems and sometimes different types of ICT gadgets simultaneously, making the adaptation process challenging.

\section{The Evolution of Technostress Definition}

Technostress has been in the interest of scholars since the 1980s, however, according to Li \& Wang (2021), it is still a relatively understudied topic. Most of the researches study the 
negative effects of technostress on business or industrial work (Maria Penado Abilleira et al., 2021) and recently an increasing amount of research is being focused on the effect of technostress on educational context (Christian et al., 2020; Gabr et al., 2021; Özgür, 2020; Panisoara et al., 2020; María Penado Abilleira et al., 2020; Wang \& Li, 2019).

Technostress was first spoken of by Brod (1984) as "an adaptive disease caused by people's inability to face new technologies in a healthy manner" (Maria Penado Abilleira et al., 2021; Ragu-Nathan et al., 2008). This definition suited when at that times enterprises just started to introduce technology in their workplace. Arnetz \& Wiholm (1997) then claimed technostress as a "state of arousal observed in certain employees who are heavily dependent on computers in their work". During this time, computers are starting to be widely used and computerised systems are starting to take place of manual works. Weil \& Rosen (2019) then defined technostress as "the stress one feels when technology takes a centre stage in their work lives, home environments and at play". Nowadays, not only has the workplace is replaced by technologies, but it has also invaded people private life. People are more and more relying on technologies and the frustration from it is inevitable. As much as ICT has facilitated numerous work tasks, technostress also has become more common (La Torre et al., 2020).

\section{Dimensions of Technostress}

There are few dimensions that emerges from the studies of technostress. Scholars found that technostress can be divided into creator, prohibitor (Li \& Wang, 2021; Mahapatra \& Pati, 2018; Ragu-Nathan et al., 2008) and individual differences (Ragu-Nathan et al., 2008).

\section{Technostress Creators}

Technostress creators represent five dimensions that create technostress in the organization (Ragu-Nathan et al., 2008; Tarafdar et al., 2007, 2019). All five dimensions will be discussed according to their effect on employees, positively and negatively.

\section{a) Techno-overload}

The stressor occurs when technology requires an employee to work faster and longer (Variya \& Patel, 2020). Employees are forced to utilised technology and work at more speed, thus expected to finish more tasks. With the availability of multiple data channels such as the internet, smartphones, gadget, and internal company sources, employees are exposed to unlimited information at a faster pace than they can handle and use effectively (Mahapatra \& Pati, 2018). This leads to information overload among employees where it becomes difficult for them to identify priorities and relevant information (Tarafdar et al., 2010). Studies also show that information or work overload has a significant influence on stress, burnout and emotional exhaustion among employees (Christian et al., 2020; van Emmerik et al., 2009), essentially leads to loss of productivity and job satisfaction (Demerouti et al., 2001).

\section{b) Techno-invasion}

Techno-invasion is the stressor related to pervasive ICTs invading personal life (Tarafdar et al., 2019). The usage of boundless technology and information essentially blurred the line between work-home balances (Mahapatra \& Pati, 2018) where an employee feels non-work time to be invaded by work demands (Tarafdar et al., 2007). Employees are facing higher expectations of constant availability; they are expected to immediately respond to workload, 
thus increasing work effort during off-hours. Delanoeije et al. (2019) suggest that telework complicates balancing work and home roles since home boundaries are more blurred where the home domain is used for work activities. The work-home conflict has been widely known as the agent of psychological distress (Zhao et al., 2020) and plays important role in hindering an individual's work performance and achievement. Techno-invasion may create role conflict and work and personal lives ambiguity (Ayyagari et al., 2011) therefore can be concluded to gives a negative impact on employees' health and well-being; mentally and physically.

\section{c) Techno complexity}

It is a situation under which, employees feel that they need to spend their time and make efforts to learn various aspects of ICT because of not possessing enough skills to deal with the complexity related to ICT (Variya \& Patel, 2020). The complexity of technology and its rapidly changing nature requires different skills, therefore adds difficulty to employees. This particular quality of an ICT makes individuals feel inadequate concerning their computer skills (La Torre et al., 2020). Due to this, employees are faced with more adaptational demand and must spend more time and energy learning a new tool (Sami \& Pangannaiah, 2006; Zhao et al., 2020), not to mention spending money on gadgets and training. The complexity of modern ICTs creates "skill discrepancy" where could lead to stress and burnout among employees (Mahapatra \& Pati, 2018). Another problem with techno-complexity is although employees are constantly updating their ICT skills, the time spent to learn it means less effort is spent in dealing with real tasks, hindering productivity and performance.

\section{d) Techno-insecurity}

Techno-security describes employees' fear of being replaced by the technology or other employees with higher ICT skills. As they perceive that new technologies may lead to automation or people with better skills and abilities will replace them in a long run (Mahapatra \& Pati, 2018), they feel threatened with job loss, leading to technology-induced job insecurity. However, this situation could lead to a positive effect on employees' overall performance and skill acquisition. (Zhao et al., 2020) state that when employees believe that high skill performance in ICT protects them from being laid off, employees are more likely to be motivated to learn new ICTs and improves their ICT skills.

\section{e) Techno-uncertainty}

As the rapid development of ICTs is driving the revolution of replacing human labour with the machine (Garcia-Murillo et al., 2018), employees are feeling the urge to be updated with new technologies. As they do not know what the following innovation will be, they feel uncertain and unsettled due to the fact that ICT is continuously changing and one needs to upgrade accordingly (Ragu-Nathan et al., 2008; Variya \& Patel, 2020). Frequent changes and upgrades of software and hardware often make employees feel incompetent, consequently makes them feel exhausted, anxious, and stressed (Wang \& Li, 2019). Innovative and technical changes also lead to employees being ambiguous about their work and job roles (Mahapatra \& Pati, 2018). However, the effect of techno-uncertainty on employees is twofold. In contrast, Zhao et al. (2020) suggest that feeling uncertainty creates the requirement to self-upgrade in ICT skills and keeping up with the improvement may benefit personal growth and increase the feeling of fulfilment. The different impact of techno-uncertainty usually relies on individual factors such as age, gender, and computer literacy level. 


\section{Technostress Prohibitors}

Technostress prohibitors represent the situational variables and organizational mechanisms that have the potential to reduce the effects of technostress (Ragu-Nathan et al., 2008; Variya \& Patel, 2020). Technostress prohibitors also can be known as coping behaviour (Tarafdar et al., 2019) which refers to an organisational mechanism that reduces stress and anxiety among employees towards technology (Ragu-Nathan et al., 2008). Three major components in si+++tuational prohibitor could be coping strategies towards technostress creator; literacy facilitation (Ragu-Nathan et al., 2008), technical support (Bondanini et al., 2020; Joo et al., 2016; Li \& Wang, 2021; Ragu-Nathan et al., 2008) and training (Joo et al., 2016; La Torre et al., 2020; Upadhyaya \& Vrinda, 2021).

Literacy facilitation is described as a mechanism that encourages and foster the sharing of ICT-related knowledge within the organization (La Torre et al., 2019). Professional development programs, teamwork, and knowledge sharing related to the use of ICT in the workplace (Atanasoff \& Venable, 2017; Li \& Wang, 2021), and user guides (Atanasoff \& Venable, 2017; Bondanini et al., 2020) are the proposed literacy facilitations that organisation could provide for employees (Atanasoff \& Venable, 2017). La Torre et al. (2020) proposes that all the efforts to prevent or mitigate technostress need to be reinforced through literacy facilitation, alongside involvement and technical support. Literacy facilitation act to reduce technostress as it helps users understand ICTs and their uses, and allows them to cope with the demands of learning new ICTs (Ragu-Nathan et al., 2008). It is proved that literacy enables an overall understanding of the implementation of terms, functionality and how they can be used (Tarafdar et al., 2015).

Technical support provision is related to technical assistance provided for employees to help them solve problems and challenges during their use of ICT. It describes activities related to end-user support that reduce the effects of technostress by solving users' ICT-related problems (La Torre et al., 2019). Furthermore, it is proven that support provided by the organisation had a significant effect in reducing employees' computer anxiety, which affected stress related to computer use (Joo et al., 2016). In addition, it is identified as one of the technostress inhibitors that have been proposed by Li \& Wang (2021) to counter the effects of technostress. Assistance provided by the organisation is deemed to be crucial to reduce employees' anxiety in using technology as it has become a major backbone for them in facing technostress, especially techno-uncertainty and techno-complexity (Bondanini et al., 2020). Significantly, providing a responsive technical team could improve technology adaptability, hence reducing technostress.

Training has been known as one of the effective tools in enhancing employees' skills and reducing anxiety at the workplace. In the effort of reducing and managing technostress, providing adequate training to users is still relevant as one of the alternatives (Upadhyaya \& Vrinda, 2021). This is because, implementation-related technostress has often been attributed to inadequate training and a lack of post-implementation knowledge-support activities (Chiappetta, 2017; La Torre et al., 2019). A study on technostress among teachers in South Korea showed that lack of training, inadequate infrastructure, and lack of support from technology specialists may induce anxiety and tension in teachers, resulting in psychological and physical stress related to technology use (Joo et al., 2016). Therefore, increased training of employees is seen to counteract the harmful effects of techno-stress (La Torre et al., 2019). 


\section{Individual Differences (Control Behaviour)}

Individual differences refer to conditions that affect personal acceptance and adaptation towards technology such as age (Arning \& Ziefle, 2009; Chung et al., 2010; Hauk et al., 2019), gender (Gefen \& Straub, 1997; Marchiori et al., 2019; Venkatesh \& Morris, 2000; Zhang et al., 2014), education background (Hsiao, 2017; Krishnan, 2017; Marchiori et al., 2019; RaguNathan et al., 2008) and technological fluency (computer confidence) (Ragu-Nathan et al., 2008; Variya \& Patel, 2020).

Arning \& Ziefle (2009) propose that age is positively associated with technology acceptance. The difficulties and constantly changing nature of technology is more acceptable to the younger generation. This is due to the fact that individuals experience deterioration of his/her motor skill over age (Reuter et al., 2012). Additionally, age also is a considerable factor to be considered, as Chung et al. (2010) found that age has a significant relationship with internet efficiency and perceived ease of use. As for gender, in general, men tend to have more confidence in their computer abilities than women (Zhang et al., 2014). Subsequently, Venkatesh \& Morris (2000) revealed that when it comes to technology confidence, men tend to have a greater extent than women. Furthermore, it is proven that technostress can be influenced by gender differences, specifically techno-complexity and techno-uncertainty where women are more affected by it than men (Marchiori et al., 2019). Women also tend to have significantly higher computer anxiety than men, which could affect the diffusion of IT usage (Gefen \& Straub, 1997).

Education is seen as one of the factors that gives a significant impact on the level of technostress among employees (Hsiao, 2017). The ability to adapt to technology and technology confidence seems to increase along with education, makes technostress decrease (Krishnan, 2017). A study by Marchiori et al. (2019) also found that individuals with lower levels of formal education are more affected by technostress, particularly techno-overload, techno-invasion, techno-complexity, and techno-uncertainty. Technological fluency also plays important role in determining the individual level of technostress and their tolerance towards it. The present generation is often referred to as "digital natives" (Upadhyaya \& Vrinda, 2021), leading to the assumption that their acceptance of technology is higher. It is found that individuals with higher confidence in their ability to use ICTs experience less technostress (Ragu-Nathan et al., 2008). Zhao et al. (2020) also confirmed a positive relationship between ICT experience and productivity, therefore inverse the association with technostress. 


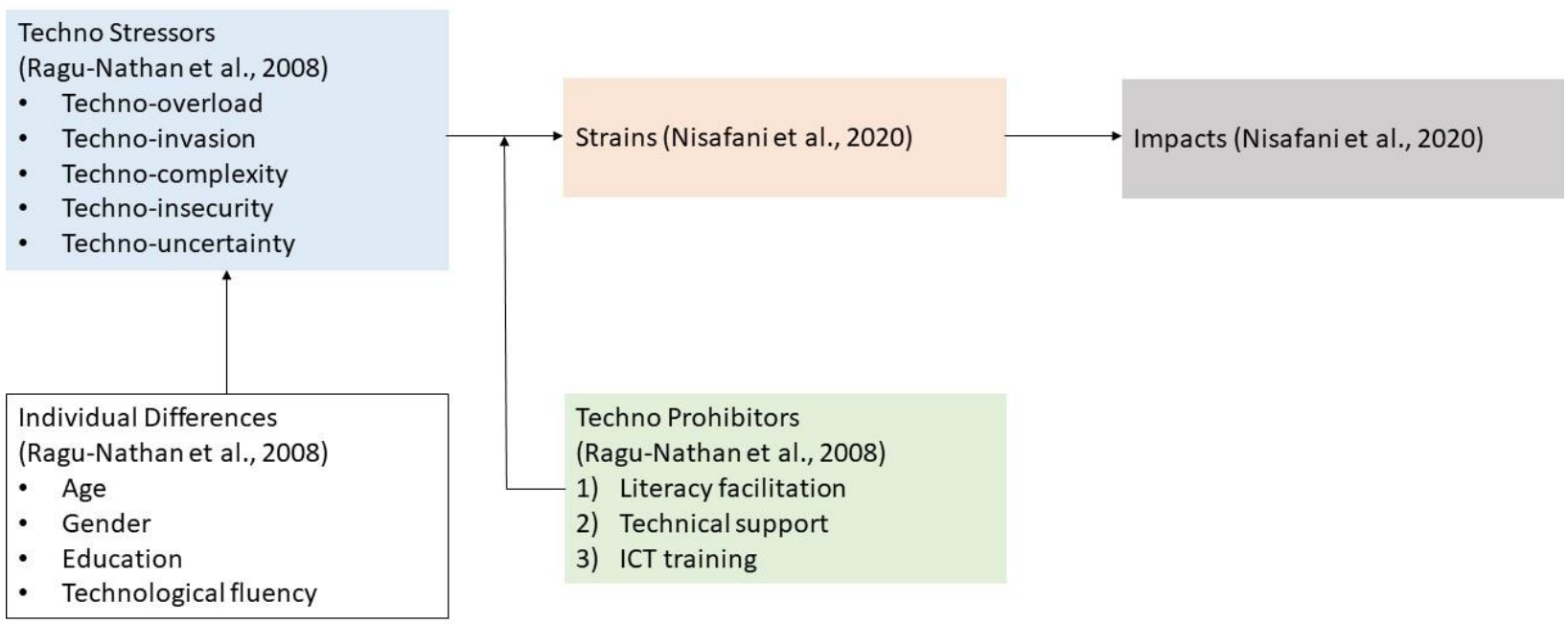

Figure 1. Work-related technostress: causes, strains, inhibitors, and impacts

\section{Positive Effect of Technostress (Techno-Eustress)}

The central and exclusive premise of the literature regarding technostress is that how it was associated with negative consequences (Tarafdar et al., 2019). The destructive effects of technostress (distress) are far better discussed in the literature, including how technology demand creates unnecessary anxiety and fear among the users. However, not all stressors are harmful to the individual. Eustress is the opposite effect of stress (as general), where it is described by Quick et al (1997) as being associated with healthy, positive outcomes (Herman, 2020), generally known as "good stress' (Herman, 2020). Techno-eustress is the phenomenon that embodies the positive stress that individuals face in their use of technology (Tarafdar et al., 2019). Numbers of researchers has starting to look into techno-eustress (Califf et al., 2020; Herman, 2020; Nelson \& Simmons, 2003; Rodriguez et al., 2021); how the demand for technology adaptability sparks as challenges and motivation, leading to potentially positive outcomes. Specifically, individuals consider the characteristics and demands of ICTS as challenges that they are motivated to tackle. The result of doing so would lead to betterment, activate coping behaviours to master the challenges in a positive way, and achieve largely affirmative and positive outcomes. In doing all of this, the individual experiences the process of "eustress" or "good" technostress (Tarafdar et al., 2019). 


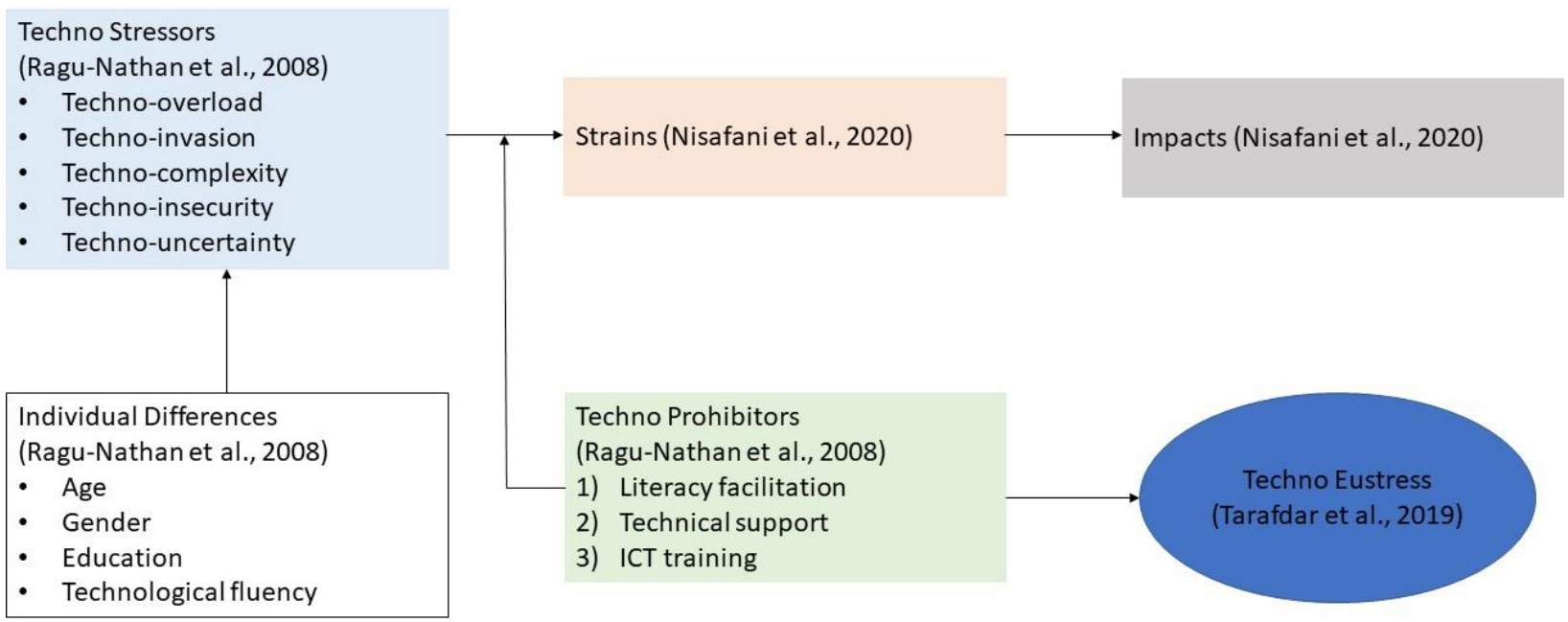

Figure 2. Work-related technostress: causes, strains, inhibitors, impacts and eustress

\section{Conclusion and Recommendation}

This paper intends to create awareness among employers and employees of technostress since it is still a foreign subject to the industries. Furthermore, in the time of the Covid-19 pandemic where all workloads are digitalized, the pressure to adapt to technology and ICTs are high. Techniques of handling technology-related stress are as important as the skill itself. This paper also intends to create awareness among employees and employers that support systems are important to reduce technostress. The implication of this paper is also to create a working environment that encourages employers to provide a supportive environment for employees.

There are several limitations identified by this paper that could guide future researchers on their study. The first is the types of training that employees need for them to master the skill and how frequent a specific training is needed for them. With most of the employees need to work remotely, so does their training should be. However, the study on elearning as a technostress prohibitor is limited. There are also lacking research that study technostress as constant or momentary feeling in employees, and what factors needed for employees to change technostress as eustress or "good stress".

From these limitations, it is suggested that subsequent studies include elearning as the factors that prohibit technostress and expand investigations to see whether the "online" elements in eLearning could bring any differences in technostress level. Future researchers could look at whether learning a technical skill online help to reduce technostress as proven by previous studies (Chiappetta, 2017; Joo et al., 2016; La Torre et al., 2019; Upadhyaya \& Vrinda, 2021) or spiking anxiety higher and make technostress worsen. Furthermore, a longitudinal study could be conducted to see the frequency of training and technical support an employee needs to reduce their technostress. Future studies could further their understanding of the relationship between individual traits and technostress creators by 
considering the various outcomes revealed in the literature. This can be done by considering other demographic factors as social context, organisation context and task in which the employees are involved. It is also suggested that the eustress topic is being studied more, for example, to see how technostress can act as eustress and what cause techno-eustress rather than techno-distress. Another suggestion to broaden the literature in technostress is to look at the impact of technostress on employees performance, health and organisation performance such as work commitment, employees engagement, user resistance and intention to use ICT, job satisfaction, and task performance (Nisafani et al., 2020).

\section{References}

Arnetz, B. B., \& Wiholm, C. (1997). Technological stress: Psychophysiological symptoms in modern offices. Journal of Psychosomatic Research, 43(1), 35-42. https://doi.org/10.1016/S0022-3999(97)00083-4

Arning, K., \& Ziefle, M. (2009). Different perspectives on technology acceptance: The role of technology type and age. Lecture Notes in Computer Science (Including Subseries Lecture Notes in Artificial Intelligence and Lecture Notes in Bioinformatics), 5889 LNCS, 20-41. https://doi.org/10.1007/978-3-642-10308-7_2

Atanasoff, L., \& Venable, M. A. (2017). Technostress: Implications for Adults in the Workforce. Career Development Quarterly, 65(4), 326-338. https://doi.org/10.1002/cdq.12111

Ayyagari, R., Grover, V., \& Purvis, R. (2011). Technostress: Technological antecedents and implications. MIS Quarterly: Management Information Systems, 35(4), 831-858. https://doi.org/10.2307/41409963

Bondanini, G., Giorgi, G., Ariza-Montes, A., Vega-Muñoz, A., \& Andreucci-Annunziata, P. (2020). Technostress dark side of technology in the workplace: a scientometric analysis. International Journal of Environmental Research and Public Health, 17(21), 1-25. https://doi.org/10.3390/ijerph17218013

Califf, C. B., Sarker, S., \& Sarker, S. (2020). The bright and dark sides of technostress: A mixedmethods study involving healthcare it1. MIS Quarterly: Management Information Systems, 44(2), 809-856. https://doi.org/10.25300/MISQ/2020/14818

Chiappetta, M. (2017). The Technostress: definition, symptoms and risk prevention. Senses Sci, 4(1), 358-361. https://doi.org/10.14616/sands-2017-1-358361

Christian, M., Purwanto, E., \& Wibowo, S. (2020). Technostress creators on teaching performance of private universities in Jakarta during covid-19 pandemic. Technology Reports of Kansai ..., 62(06), 2799-2809. http://www.academia.edu/download/64028209/TRKU Vol 62 No 06\%232 2020.pdf

Chung, J. E., Park, N., Wang, H., Fulk, J., \& Mclaughlin, M. (2010). Age differences in perceptions of online community participation among non-users: An extension of the Technology Acceptance Model. Computers in Human Behavior, 26(6), 1674-1684. https://doi.org/10.1016/j.chb.2010.06.016

Delanoeije, J., Verbruggen, M., \& Germeys, L. (2019). Boundary role transitions: A day-to-day approach to explain the effects of home-based telework on work-to-home conflict and home-to-work conflict. Human Relations, 72(12), 1843-1868.

https://doi.org/10.1177/0018726718823071

Demerouti, E., Bakker, A. B., Nachreiner, F., \& Schaufeli, W. B. (2001). THE JOB DEMANDRESOURCES MODEL FOR BURNOUT.pdf (pp. 499-512).

Gabr, H. M., Soliman, S. S., Allam, H. K., \& Raouf, S. Y. A. (2021). Effects of remote virtual work environment during COVID-19 pandemic on technostress among Menoufia University 
Staff, Egypt: a cross-sectional study. Environmental Science and Pollution Research, 2004. https://doi.org/10.1007/s11356-021-14588-w

Garcia-Murillo, M., MacInnes, I., \& Bauer, J. M. (2018). Techno-unemployment: A framework for assessing the effects of information and communication technologies on work. Telematics and Informatics, 35(7), 1863-1876.

https://doi.org/10.1016/j.tele.2018.05.013

Gefen, D., \& Straub, D. W. (1997). Gender differences in the perception and use of e-mail: An extension to the technology acceptance model. MIS Quarterly: Management Information Systems, 21(4), 389-400. https://doi.org/10.2307/249720

Hauk, N., Göritz, A. S., \& Krumm, S. (2019). The mediating role of coping behavior on the agetechnostress relationship: A longitudinal multilevel mediation model. PLOS ONE, 14(3), 1-22. https://doi.org/10.1371/journal.pone.0213349

Herman, H. (2020). Eustress instead of Distress : Open Universiteit.

Hsiao, K. L. (2017). Compulsive mobile application usage and technostress: The role of personality traits. Online Information Review, 41(2), 272-295. https://doi.org/10.1108/OIR-03-2016-0091

Joo, Y. J., Lim, K. Y., \& Kim, N. H. (2016). The effects of secondary teachers' technostress on the intention to use technology in South Korea. Computers and Education, 95, 114-122. https://doi.org/10.1016/j.compedu.2015.12.004

Krishnan, S. (2017). Personality and espoused cultural differences in technostress creators. Computers in Human Behavior, 66, 154-167. https://doi.org/10.1016/j.chb.2016.09.039

La Torre, G., De Leonardis, V., \& Chiappetta, M. (2020). Technostress: how does it affect the productivity and life of an individual? Results of an observational study. Public Health, 189, 60-65. https://doi.org/10.1016/j.puhe.2020.09.013

La Torre, G., Esposito, A., Sciarra, I., \& Chiappetta, M. (2019). Definition, symptoms and risk of techno-stress: a systematic review. International Archives of Occupational and Environmental Health, 92(1), 13-35. https://doi.org/10.1007/s00420-018-1352-1

Li, L., \& Wang, X. (2021). Technostress inhibitors and creators and their impacts on university teachers' work performance in higher education. Cognition, Technology and Work, 23(2), 315-330. https://doi.org/10.1007/s10111-020-00625-0

Mahapatra, M., \& Pati, S. P. (2018). Technostress Creators and Burnout. 70-77. https://doi.org/10.1145/3209626.3209711

Marchiori, D. M., Mainardes, E. W., \& Rodrigues, R. G. (2019). Do Individual Characteristics Influence the Types of Technostress Reported by Workers? International Journal of Human-Computer Interaction, 35(3), 218-230. https://doi.org/10.1080/10447318.2018.1449713

Matrajt, L., \& Leung, T. (2020). Effectiveness of Social Distancing for COVID-19. Cdc, 26(8). https://www.medrxiv.org/content/10.1101/2020.03.03.20028423v3.

Nelson, D. L., \& Simmons, B. L. (2003). Eustress: an Elusive Construct, an Engaging Pursuit. Research in Occupational Stress and Well Being, 3(03), 265-322. https://doi.org/10.1016/S1479-3555(03)03007-5

Nisafani, A. S., Kiely, G., \& Mahony, C. (2020). Workers' technostress: a review of its causes, strains, inhibitors, and impacts. Journal of Decision Systems, 00(00), 1-16. https://doi.org/10.1080/12460125.2020.1796286

Özgür, H. (2020). Relationships between teachers' technostress, technological pedagogical content knowledge (TPACK), school support and demographic variables: A structural equation modeling. Computers in Human Behavior, 112(July). 
https://doi.org/10.1016/j.chb.2020.106468

Panisoara, I. O., Lazar, I., Panisoara, G., Chirca, R., \& Ursu, A. S. (2020). Motivation and continuance intention towards online instruction among teachers during the COVID-19 pandemic: The mediating effect of burnout and technostress. International Journal of Environmental Research and Public Health, 17(21), 1-29.

https://doi.org/10.3390/ijerph17218002

Ragu-Nathan, T. S., Tarafdar, M., Ragu-Nathan, B. S., \& Tu, Q. (2008). The consequences of technostress for end users in organizations: Conceptual development and validation. Information Systems Research, 19(4), 417-433. https://doi.org/10.1287/isre.1070.0165

Reuter, E. M., Voelcker-Rehage, C., Vieluf, S., \& Godde, B. (2012). Touch perception throughout working life: Effects of age and expertise. Experimental Brain Research, 216(2), 287-297. https://doi.org/10.1007/s00221-011-2931-5

Rodriguez, C. F. C., Choudrie, J., Rodriguez, C. F. C., \& Choudrie, J. (2021). technostress : Exploring and understanding the bright and dark sides before and during Covid-19 The impact of different organizational environments on technostress: Exploring and understanding the bright and dark sides before and during Covid-19.

Sami, L. K., \& Pangannaiah, N. B. (2006). "Technostress": A literature survey on the effect of information technology on library users. Library Review, 55(7), 429-439. https://doi.org/10.1108/00242530610682146

Tarafdar, M., Cooper, C. L., \& Stich, J. F. (2019). The technostress trifecta - techno eustress, techno distress and design: Theoretical directions and an agenda for research. Information Systems Journal, 29(1), 6-42. https://doi.org/10.1111/isj.12169

Tarafdar, M., Pullins, E. B., \& Ragu-Nathan, T. S. (2015). Technostress: Negative effect on performance and possible mitigations. Information Systems Journal, 25(2), 103-132. https://doi.org/10.1111/isj.12042

Tarafdar, M., Tu, Q., Ragu-Nathan, B. S., \& Ragu-Nathan, T. S. (2007). The impact of technostress on role stress and productivity. Journal of Management Information Systems, 24(1), 301-328. https://doi.org/10.2753/MIS0742-1222240109

Tarafdar, M., Tu, Q., \& Ragu-Nathan, T. (2010). Impact of technostress on end-user satisfaction and performance. Journal of Management Information Systems, 27(3), 303334. https://doi.org/10.2753/MIS0742-1222270311

Upadhyaya, P., \& Vrinda. (2021). Impact of Technostress on Academic Productivity of University Students. Education and Information Technologies, 26(2). https://doi.org/10.1007/s10639-020-10319-9

van Emmerik, I. J. H., Bakker, A. B., \& Euwema, M. C. (2009). Explaining employees' evaluations of organizational change with the job-demands resources model. Career Development International, 14(6), 594-613.

https://doi.org/10.1108/13620430910997312

Variya, P. B., \& Patel, N. (2020). Technostress : A Conceptual Framework. February.

Venkatesh, V., \& Morris, M. G. (2000). Why don't men stop asking for directions? Gender, Social Influence and their role in society. MIS Quarterly, 24(1), 115-139.

Wang, X., \& Li, B. (2019). Technostress among teachers in higher education: An investigation from multidimensional person-environment misfit. Frontiers in Psychology, 10(JULY). https://doi.org/10.3389/fpsyg.2019.01791

Weil, M. M., \& Rosen, L. D. (2019). Coping with Technology @ Work @ Home @ Play. Coping With The Future, 151-165. https://doi.org/10.4324/9780203712894-10

Zhang, L., Nyheim, P., \& Mattila, A. S. (2014). The Effect of Power and Gender on Technology 
Acceptance. Journal of Hospitality and Tourism Technology, 5, 299-314.

Zhao, X., Xia, Q., \& Huang, W. (2020). Impact of technostress on productivity from the theoretical perspective of appraisal and coping processes. Information and Management, 57(8), 103265. https://doi.org/10.1016/j.im.2020.103265

Zito, M., Ingusci, E., Cortese, C. G., Giancaspro, M. L., Manuti, A., Molino, M., Signore, F., \& Russo, V. (2021). Does the end justify the means? The role of organizational communication among work-from-home employees during the covid-19 pandemic. International Journal of Environmental Research and Public Health, 18(8). https://doi.org/10.3390/ijerph18083933 